\title{
Genetic Transformation of Dendrobium 'Sonia Earsakul' with Antisense Carica papaya ACOI Gene
}

\author{
Piyanuch Sornchai ${ }^{1,2}$, Rakchanok Koto ${ }^{3}$, Parichart Burns ${ }^{1,4}$, Sontichai Chanprame ${ }^{1,5}$, Wachiraya Imsabai ${ }^{6} \&$ \\ Sermsiri Chanprame ${ }^{1,2,6}$ \\ ${ }^{1}$ Center for Agricultural Biotechnology, Kasetsart University, Kamphaeng Saen Campus, Nakhon Pathom 73140 \\ and Center of Excellence on Agricultural Biotechnology: (AG-BIO/PERDO-CHE), Bangkok, Thailand \\ ${ }^{2}$ Center for Advanced Studies for Agriculture and Food, (CASAF, NRU-KU), Kasetsart University Institute for \\ Advanced Studies, Kasetsart University, Bangkok, Thailand \\ ${ }^{3}$ Department of Biology, Faculty of Science, Srinakharinwirot University, Bangkok, Thailand \\ ${ }^{4}$ National Center for Genetic Engineering and Biotechnology, 113Thailand Science Park, Phahonyothin Road, \\ Khlong Nueng, Khlong Luang, PathumThani, Thailand \\ ${ }^{5}$ Department of Agronomy, Faculty of Agriculture at Kamphaeng Sean, Kasetsart University, Kamphaeng Saen \\ Campus, Nakhon Pathom, Thailand \\ ${ }^{6}$ Department of Horticulture, Faculty of Agriculture at Kamphaeng Sean, Kasetsart University, Kamphaeng Saen \\ Campus, Nakhon Pathom, Thailand \\ Correspondence: Sermsiri Chanprame, Department of Horticulture, Faculty of Agriculture at Kamphaeng Sean, \\ Kasetsart University, Kamphaeng Saen Campus, Nakhon Pathom, Thailand. E-mail: agrsrc@ku.ac.th
}

Received: July 4, 2015

doi:10.5539/mas.v9n12p125
Accepted: August 13, 2015

Online Published: October 31, 2015

URL: http://dx.doi.org/10.5539/mas.v9n12p125

\begin{abstract}
Dendrobium orchid is one of the major export cut flowers not only in Thailand but also for several tropical countries. However, the production of ethylene by their flowers causes a shorter vase life. Flowers that contained lower levels of ethylene usually exhibited delayed senescence and consequently prolonged vase life. The transfer of antisense ACC oxidase (ACO) gene into orchid, in theory, may leads to decreased ethylene production because this gene can down regulates the ethylene biosynthesis pathway. This study focuses on the transformation and the existence and expression of the antisense $A C O 1$ gene from papaya, namely $(C P-A C O 1)$, which was transferred in to Dendrobium 'Sonia Earsakul'. The successful stable transformation event obtained and the existence of the transferred gene was determined using PCR, dot blot hybridization and Southern blot hybridization techniques. The results revealed that antisense $C P$-ACO1 and hygromycin phosphotransferase (hpt) gene existed in all transgenic lines confirmed by PCR technique. The genomic dot blot confirmed the incorporation of the transgene in transgenic plant genome. Southern blot hybridization revealed the existed of one to four sets of the gene in transgenic lines. The expression of antisense $C P-A C O 1$ gene was analyzed through the level of ACO enzyme activity and ethylene production in transgenic orchid. All of the transgenic lines had lower ACO enzyme activity and lower ethylene production than that of the non-transgenic orchid plants.
\end{abstract}

Keywords: transgenic orchid, Dendrobium, antisense, ACC oxidase, ethylene

\section{Introduction}

Dendrobium orchid as one of the major cut flower in Thailand, have been export world-wide. However, the production of ethylene by their flowers caused shorter vase-life of orchid especially during the export storage. The senescence of flowers including orchid is mainly regulate by endogenous ethylene and the ethylene production is increased by autocatalytic reaction (Goh et al., 1985). Ethylene is synthesized from the methionine, through s-adenosylmethionine (SAM) and 1-aminocyclopropane-1-carboxylate (ACC) (Yang and Hoffman 1984; Ables et al., 1992). The ethylene biosynthesis has two major enzymes: ACC synthase (ACS) and ACC oxidase (ACO) that are involved the rate of ethylene production. Ethylene production can be reduce by several approaches such as applying ethylene chemical inhibitor; aminooxyacetic acid (AOA) and 1-methylcyclopropane (1-MCP); and environment control; avoiding dry storage and water stress condition 
(Scariot et al., 2014).

Currently, several approaches involve with genetic transformation illustrated a very effective of controlling the ethylene synthesis such as antisense RNA technology and virus-induced gene silencing (Stearn and Glick 2003). Down-regulation of gene expression by homologous antisense RNA has been successful in a number of plants. For example, transgenic tomato transformed with antisense $A C O$ gene from tomato demonstrated a $87 \%$ reduction of ethylene production in ripening fruit and $68 \%$ reduction of ethylene in wounded leaves (Hamilton et al., 1990). Oeller et al.(1991) reported that transgenic tomato transformed with antisense ACS from tomato showed a $99.5 \%$ reduction of ethylene production in ripening fruit. In addition, there are reports in other plants such as carnation flowers (Savin et al., 1995) cantaloupe melon (Ayub et al. 1996) tobacco (Knoester et al., 1997) and pear (Gao et al., 2007).

The above mentioned reports demonstrated the successful of using the genes among the same plant species. However, genes involve in ethylene biosynthesis in several plants had high percentage of sequence similarity and the antisense technology does not required a hundred percent of sequence similarity. Therefore, genes from different plant species can be used. In 1997, Bolitho et al., showed a 95\% reduction of ethylene production in tomato using antisense $A C O$ from apple. In addition, the heterologous antisense RNA transformation for down-regulate ethylene production has been successful in many plants such as tobacco with the gene from tomato (Einset, 1996), broccoli with the gene from tomato (Henzi et al., 1999), melon with the gene from apple (Silva et al., 2004) as well as petunia with the gene from broccoli (Huang et al., 2007).

According to researches, down regulation of the $A C C$ or $A C O$ gene in transgenic plants not only reduced ethylene production but also prolonged shelf life. However, there was no report on antisense $A C O$ transformation in Dendrobium orchid. Thus, transformation of antisense $A C O$ gene from papaya (Carica papaya; dicotyledonous plant), that has $55 \%$ identity with $A C O$ gene of Dendrobium orchid into Dendrobium 'Sonia Earsakul' (dicotyledonous plant) in this report not only ought to be beneficial research validating the decreased ethylene production in orchid. Additionally, it is also illustrate the effectiveness of antisense technology over the mono- and di-cotyledonous species.

\section{Method}

\subsection{The Construction of Binary Vector Harboring Antisense CP-ACO1 Gene}

Antisense $C P-A C O 1$ gene was cloned from cDNA of Carica papaya $C P-A C O 1$. using primers aCPACO1F (forward) 5'-GGAGCTCGCTAGCCACCATGATCTCTCATGACCTGAT GGA-3' and aCPACO1 R (reverse) : 5'-GGTCTAGACCAT GGTCTACCAGAGATGGTG CT GG-3'. Finally antisense $C P$ - $A C O 1$ was inserted into pCAMBIA 1301 vector (CSIRO, Australia) to became pCAMBIA1301a $A C O 1$ plasmid that includes antisense CP-ACO1 and hygromycin phosphotransferase gene (hpt) as a selectable marker under the control of CaMV35S promoter (Figure 1). The plasmid was transferred into Agrobacterium tumefaciens strain AGL-1.

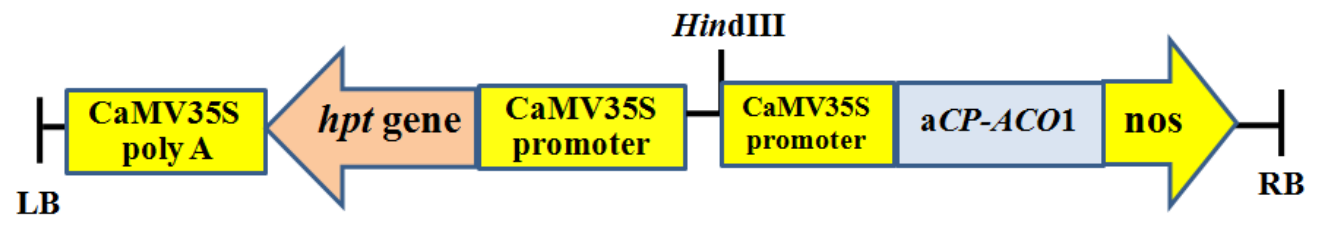

Figure 1. The diagram of pCAMBIA $1301 \mathrm{a} A C O 1$ containing antisense $C P$-ACO1 gene and hygromycin phosphotransferase ( $h p t$ ) gene driven by the CaMV35S promoter

\subsection{Protocorm Like Bodies (PLBS) Transformation}

The approximately $2 \mathrm{~mm}$ thick of PLBs-derived transversely thin cell layers (tTCLs) of Dendrobium 'Sonia Earsakul' were sonicated 6 seconds for wounding and were pre-cultured in Vacin and Went (VW) liquid medium (1949) supplemented with $15 \%$ coconut water and $1 \%$ sucrose for three days. The tTCLs were then immersed in the suspension of A. tumefaciens $(5 \times 108 \mathrm{cell} / \mathrm{ml})$ in VW liquid medium for 60 minutes. For co-cultivation, the tTCLs were transferred onto fresh VW solid medium supplemented with $200 \mu \mathrm{M}$ acetosyringone for 2 days. Agrobacterium was washed in VW liquid medium containing $500 \mathrm{mg} / \mathrm{l}$ cefotaxime for 60 minutes. The infected tTCLs were selected on VW solid medium supplemented with $30 \mathrm{mg} / 1$ hygromycin and $250 \mathrm{mg} / \mathrm{l}$ cefotaxime for 1 month and then transferred into VW liquid medium supplemented with the same concentration of both 
antibiotics for 2 months. The survived cells grew into small PLBs and were separately cultured on VW solid medium supplemented with $15 \%$ homogenate potato, $1 \%$ sucrose and $0.2 \%$ activated charcoal for plantlets regeneration.

\subsection{Transplanting of Transgenic Plantlets}

The number of 25 plantlets from each selected transformed line and a non-transgenic Den. 'Sonia Earsakul' line were multiplied and rooted on VW solid medium supplemented with $20 \%$ coconut water, $2 \%$ sucrose and $0.2 \%$ activated charcoal. Rooted plantlets were transplanted onto coconut coir and grown in the biosafety greenhouse. The number of 5 plants from each line were randomly selected for the investigation for the studies on the stability and expression of antisense $C P-A C O 1$ gene.

\subsection{Analysis of the Transferred Gene Stability}

\subsubsection{PCR Analysis}

Genomic DNA was extracted from young leaves of transgenic and non-transgenic Den. 'Sonia Earsakul' according to Doyle and Doyle (1987). The stability of transferred genes; antisense CP-ACO1 and hpt gene was analyzed by PCR technique with specific primers (Table 1). The 18S ribosomal RNA was used as internal control. PCR product was verified on $1 \%$ agarose gel electrophoresis.

Table 1. List of primers used in detection of the transferred genes by PCR technique

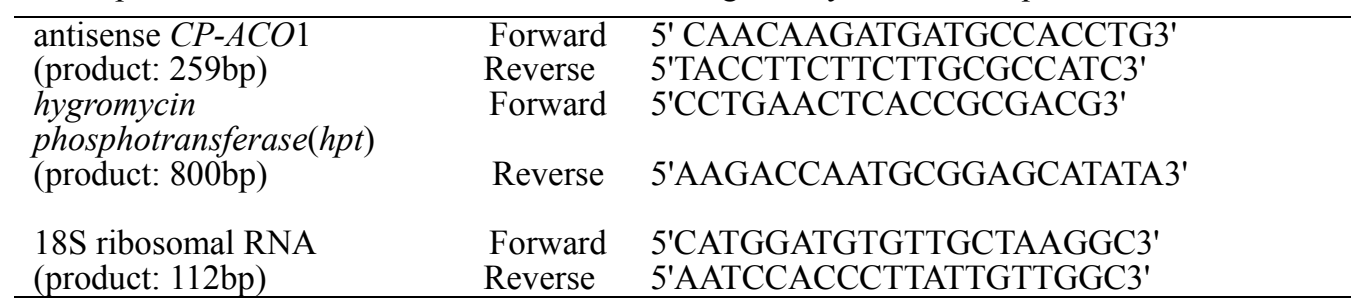

\subsubsection{Dot Blot Analysis}

Genomic DNA of transgenic and non-transgenic Den. 'Sonia Earsakul' was extracted from mature leaves following the Doyle and Doyle (1987). The approximately of $0.1 \mu \mathrm{g}$ denatured DNA was dotted on nylon membrane and hybridized with antisene $C P$ - $A C O 1$ probe subsequently exposed to x-ray film to visualize the signal.

\subsubsection{Southern Blot Analysis}

Genomic DNA of transgenic and non-transgenic was extracted from mature leaves. The amount $80 \mu \mathrm{g}$ of genomic DNA was digested with restriction enzyme HindIII. The DNA fragments were separated on $1.5 \%$ agarose gel electrophoresis. For blotting, gel was subjected to depurination with $0.25 \mathrm{M} \mathrm{HCl}$ followed by denaturation with $0.4 \mathrm{~N} \mathrm{NaOH}$ to denature the double-stranded DNA. The DNA fragments were transferred onto nylon membrane (Amersham Biosciences) by capillary transfer technique with $0.4 \mathrm{~N} \mathrm{NaOH}$ solution. The membrane were then soaked in $2 \mathrm{xSSC}$ for $5 \mathrm{~min}$ and incubated at $80^{\circ} \mathrm{C}$ for $2 \mathrm{hrs}$.

The membrane was probed in a hybridization solution (5x SSC, $0.1 \%$ N-lauroylsacosin, $0.02 \%$ SDS, $1 \%$ blocking reagent (Roche, Germany) that contained DNA probe (part of CaMV35S promoter to antisense $C P-A C O 1)$ and incubated at $65^{\circ} \mathrm{C}$ for $16 \mathrm{hrs}$. After hybridization, membrane was washed twice using washing buffer I ( $2 \mathrm{xSSC}$ and $0.1 \%$ SDS) and twice with washing buffer II $(0.5 \mathrm{XSSC}, 0.1 \% \mathrm{SDS})$ at $65^{\circ} \mathrm{C}$ for 15 minutes each time. Subsequently, the membrane was soaked in a blocking solution (1x maleic acid buffer and $1 \%$ blocking reagent) for 30 minutes and then soaked in the solution that contained $0.2 \mathrm{mg} / \mathrm{l}$ anti-digoxigenin-AP (Roche, Germany) for $1 \mathrm{hr}$. The membrane was then washed twice by washing buffer (1x maleic acid buffer and $0.3 \%$ Tween 20$)$. To detect the hybridized bands, membrane was treated with detection buffer $(0.1 \mathrm{M}$ Tris-HCl $\mathrm{pH}$ 9.5, $0.1 \mathrm{M} \mathrm{NaCl}$ and CDP-Star (Roche, Germany) for 10 min then exposed to x-ray film to visualize the signal.

\subsection{Analysis of ACC Oxidase Enzyme Activity}

ACC oxidase enzyme activity of mature leaves of 9-months-old transgenic and non-transgenic orchids was analyzed as described by Kato and Hyodo (1999). Three grams of leaf tissue was homogenized in $10 \mathrm{ml}$ of extraction buffer $(0.1 \mathrm{M}$ Tris- $\mathrm{HCl} \mathrm{pH} \mathrm{7.2,30 \%} \mathrm{glycerol,} 10 \mathrm{mM}$ sodium ascorbate and $5 \mathrm{mM}$ dithiothreitol) and centrifuged at $12,000 \mathrm{rpm}$ at $4 \mathrm{oC}$ for $20 \mathrm{~min}$. The supernatant was analyzed for ACC oxidase activity in reaction 
buffer $\left(0.1 \mathrm{M}\right.$ Tris- $\mathrm{HCl} \mathrm{pH} 7.2,1 \mathrm{mM}$ ACC, $30 \%$ glycerol, $10 \mathrm{mM}$ sodium ascorbate, $10 \mathrm{mM} \mathrm{NaHCO}_{3}$ and $50 \mu \mathrm{M}$ $\mathrm{FeSO}_{4}$ ) and incubated at $37 \mathrm{oC}$ in a closed test tube. Gas sample was collected and injected into a gas chromatography (Shimadzu GC 14A, Kyoto, Japan). The ACC oxidase enzyme activity was determined as the ethylene content that converted from ACC in reaction. The experiments were set out using a completely randomized design (CRD) with five replications, with five plants for each replication

\subsection{Analysis of Ethylene Production}

Ethylene production of whole plant, both transgenic and non-transgenic orchids, at 1, 6, 9 and 12 months after transplanting were measured according to Bolitho et al. (1997). The whole orchid plant was put into a plastic container with a sealed lid and placed at $25 \mathrm{oC}$ for 2 hours. Gas samples $(1 \mathrm{ml})$ were collected and analyzed for ethylene using gas chromatography (Shimadzu GC 14A, Kyoto, Japan). The experiments were set out using a completely randomized design (CRD) with five replications, with five plants for each replication

\section{Results and Discussion}

The transformation result showed that 18 out of 1,852 (0.97\%) inoculated tTCLs survived and grew to PLBs on hygromycin containing selective medium. However, only 4 PLBs were successful regenerated that make $22.22 \%$ of survived PLBs and only $0.22 \%$ of inoculated tTCLs. From these 4 PLBs, several plantlets regenerated (Figure 2) and the analysis by PCR initially confirmed that they were transformed (data not shown). However, only a few showed normal growth while several showed abnormal such as stunt and etiolate pseudobulb. Regarding to the case that single PLB may form from multiple cells, thus each regenerated plantlet was considered to result from different origin of transformed cell.

The difference in transformation event may result to the different expression of the transferred genes due to the difference in their copy number and insertion position to the host genome. Ethylene was known to involve in several stages of plant development including seedling development through the interference of the other hormones activities (Abeles et al., 1992). Therefore, it is not surprise that the expression of antisense $A C O 1$ gene could interfere the plant regeneration processes and resulted to the unable to regenerate of PLB and the abnormality of plantlets. This finding was supported by the research done by Bovy et al. (1999) in which abnormal carnation plantlets were founded in the case of the transformation with ethylene receptor gene. In this report, the orchid (monocotyledonous) was transformed with the antisense $C P-A C O 1$ from papaya (dicotyledonous) which is 55\% similar with ACO gene of orchid, hence, low impact on ethylene production during developmental stage may occur (Einset, 1996; Gupta et al., 2008) and allowed 4 normal plantlets yielded.

These four normal transgenic lines were coded as "Antisense Earsakul (AE)" 1, 2, 3 and 4 and each line were multiply to obtained 25 plantlets prior to transplanted in a biosafety greenhouse. The number of 5 plants from each line were randomly selected for the investigation in this report. All of them demonstrated normal vegetative growth and the similar morphological characters compared with wild type during the first year of growing.
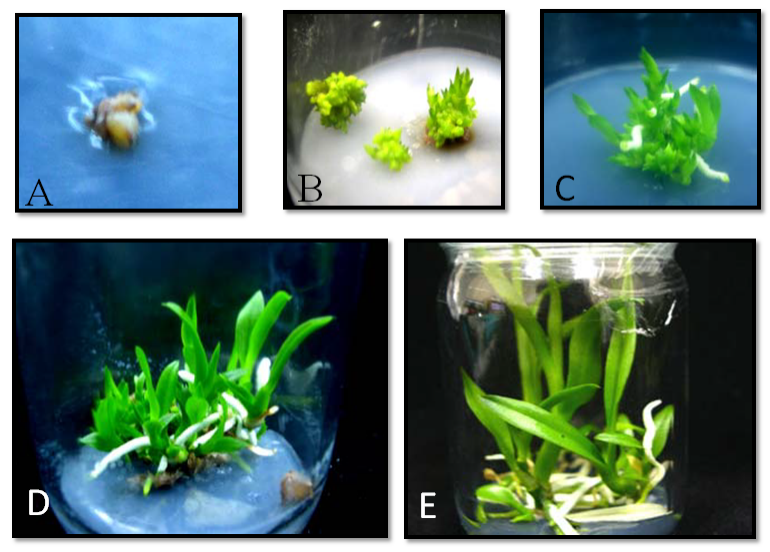

Figure 2. The dead PLB (A) and the survived and regenerated PLBs (B) Transgenic plantlets developing from PLBs cultured on VW solid medium supplemented with $20 \%$ coconut water, $2 \%$ sucrose and $0.2 \%$ activated charcoal for 10(C),14(D) and 18(E) weeks

\subsection{Analysis of the Transferred Gene Stability}

Genomic DNA from young leaves of one-month-old transgenic orchid lines (AE1-AE4) were investigated for 
the existence of the antisense $C P-A C O 1$ and $h p t$ genes using PCR technique with primers specific for each gene as listed in Table 1. The result confirmed the existence of antisense $C P-A C O 1$ and hpt genes in all of these four transgenic lines (Figure 3). The genomic DNA dot blot analysis also reconfirmed the existence of antisense $C P-A C O 1$ gene in 6-month-old transgenic plants. Positive signals were detected in all replications of 4 transgenic lines (Figure 4). The Southern blot analysis of genomic DNA of transgenic orchid revealed the copy number of $C P-A C O 1$ gene in each transgenic line. The AE1 line contained one copy of antisense $C P-A C O 1$ gene, AE2 and AE4 lines contained three copies whilst AE3 line had 4 copies (Figure 5).

The insertion of the transgene resulted from Agrobacterium-mediated genetic transformation may occurs as single copy or multiple copies in which the position also vary. The expression of the transferred genes is not influence only by copy number but also the insertion position as well (Windels et al., 2008). Several research reports also revealed multiple copies of the transgene inserted in the host genome in genetic transformation of orchid species such as Den. nobile (Men et al., 2003), Phalaenopsis (Sjahril et al., 2003), and Cymbidium (Chin et al., 2003). As Southern blot can explain only copy number but not the insertion position of the transgene, therefore, the expression of antisense $C P-A C O 1$ gene in these orchid lines is yet to study.

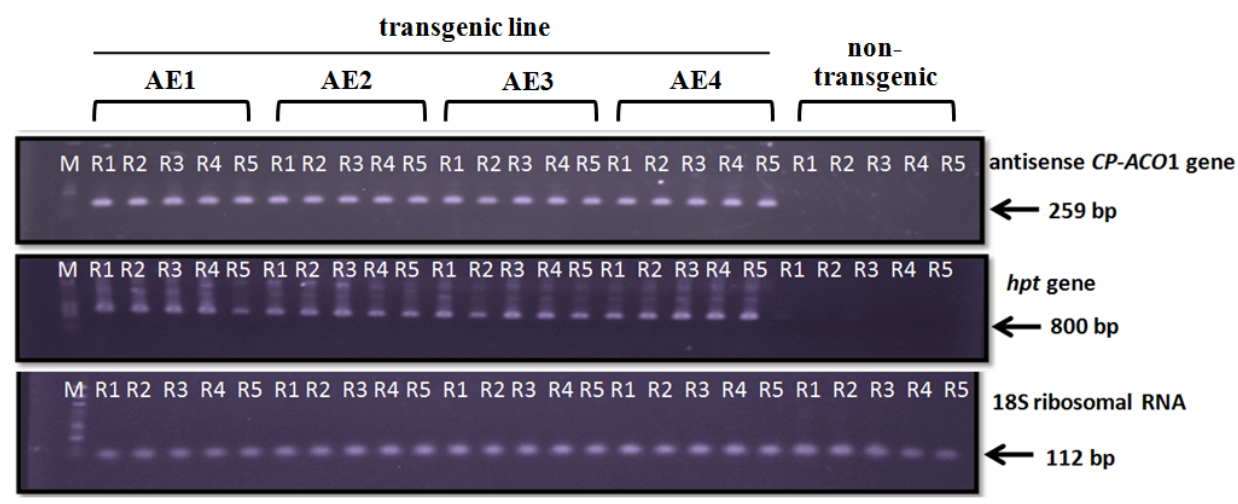

Figure 3. PCR analysis to confirm the existence of antisense CP-ACO1 and hpt genes and in 4 lines of 1-month-old transgenic Dendrobium 'Sonia Earsakul' (AE1-AE4). The18S ribosomal RNA PCR products were used as the internal control

M: Standard DNA marker- GeneRulerTM 100 bp Ladder (Fermentas)

R1-R5: The 5 repetitive in each line of non-transgenic and transgenic Den. 'Sonia Earsakul'

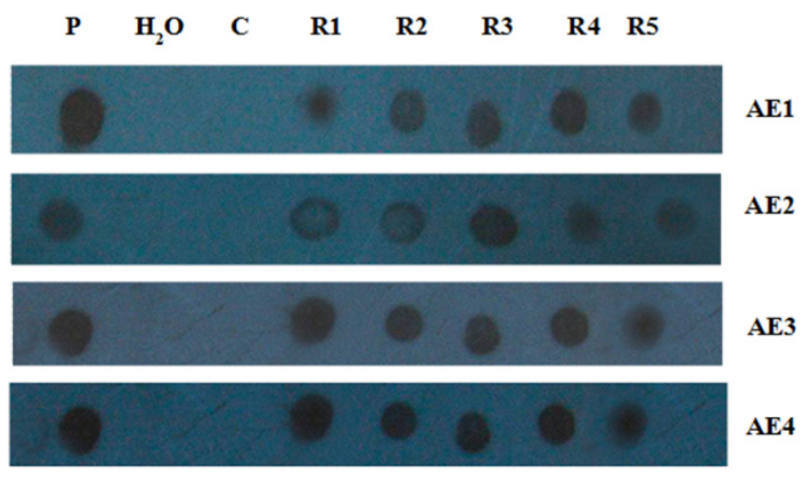

Figure 4. Dot blot hybridization of genomic DNA from 6-month-old Dendrobium 'Sonia Earsakul' transgenic lines (AE1 $\mathrm{AE} 2 \mathrm{AE} 3$ and $\mathrm{AE} 4$ ) probed with antisense $C P-A C O 1$

P: Hybridizing dot using pCAMBIA $1301 \mathrm{a} A C O 1$ as a DNA template

$\mathbf{H}_{2} \mathbf{O}$ : Negative control $\left(\mathrm{dH}_{2} \mathrm{O}\right.$ in replacement of DNA template)

C: Negative control (genomic DNA from non-transgenic orchid line)

R1-R5: The 5 repetitive in each line of transgenic orchids 

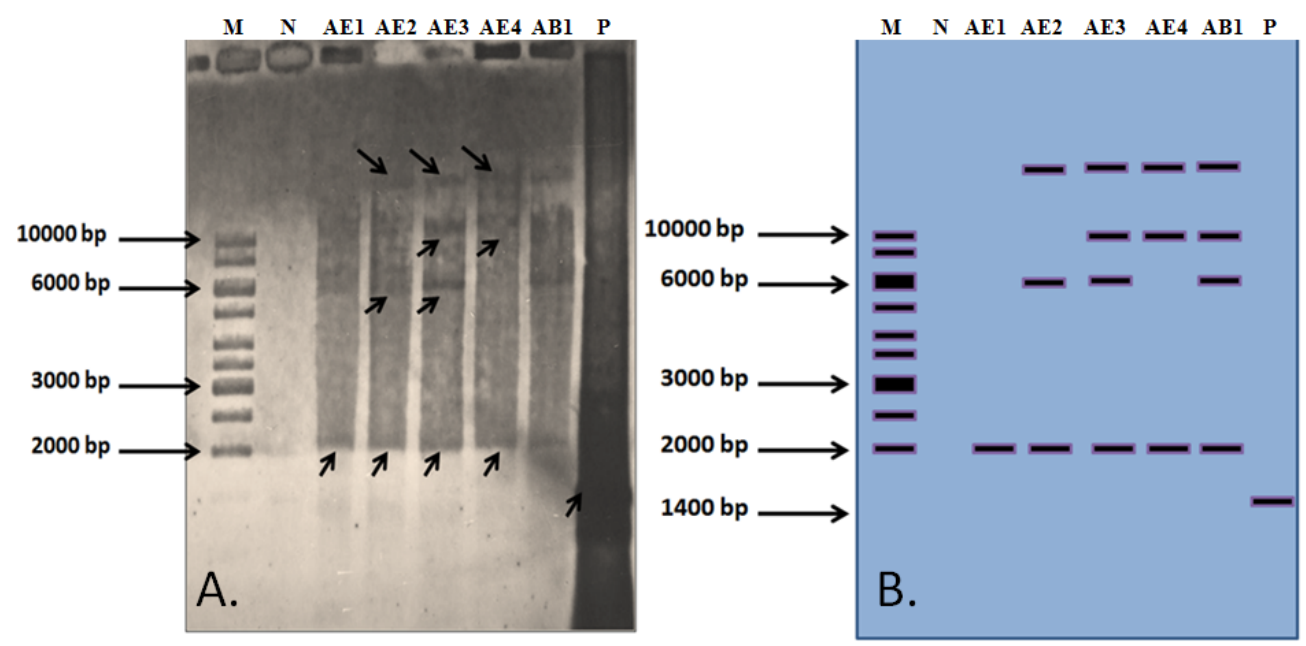

Figure 5. The Southern blot hybridization of 4 transgenic lines of Dendrobium 'Sonia Earsakul' (AE1 AE2 AE3 and AE4) probed with the part of CaMV35S promoter to antisense $C P$ - $A C O 1$ gene exposed on x-ray film (A) and its diagram to demonstrate the obvious hybridization band (B)

M: Standard DNA marker: GeneRulerTM 100 bp Ladder (Fermentas)

$\mathbf{N}$ : Negative control (non-transgenic Den. 'Sonia Earsakul')

P: PCR product of pCAMBIA1301a $A C O 1$ as a DNA template.

AB1: Positive control (transgenic Den. 'Sonia Bom17')

\subsection{ACC oxidase (ACO) Enzyme Activity and Ethylene Production of Transgenic and Non-Transgenic Dendrobium 'Sonia Earsakul'}

The analysis result of ACO enzyme activity in mature leaves of 9-month-old Den. 'Sonia Earsakul' which was transformed with antisense $C P-A C O 1$ gene revealed that all of transgenic lines showed less ACO enzyme activity than that of non-transgenic orchids (Figure 6). The result suggested that the transferred antisense $C P-A C O 1$ could express and its mRNA bound to ACO mRNA in host cells and formed double stranded mRNA resulted in the inhibition of the $A C O$ gene expression in transgenic Dendrobium. However, the levels of ACO enzyme activity were differed in 4 transgenic lines (5.49 - 59.38\% non-transgenic line) may be because of the differed in copy number and inserted site of antisense CP-ACO1 in host genome (Windels et al., 2008).

Ethylene production of whole plants of transgenic and non-transgenic orchids at 1, 6, 9 and 12 months after transplanting was measured and the results also revealed similar trend of ACO activity that all of transgenic lines showed less ethylene production than that of non-transgenic orchid (Figure 7). The effectiveness of antisense $C P-A C O 1$ resulting from the CaMV35S promoter that controlled the gene to be expressed in all tissue, at all developmental stage of plants as the similar result observed in strawberry by De Mesa et al. (2004). Therefore the ethylene production of transgenic lines was lower than in non-transgenic line at all time of testing during the first year of planting.

For the time course study of ethylene production, when the age of plant increased, ethylene production decreased. The high ethylene production in the first month may owe the production of wounding ethylene in the newly transplanted orchid. The decrease in 6-12-month-old may be due the increase of auxin which inhibits the ethylene in the plants as Picton et al. (1993) and Pret'ov'a et al. (2001) also reported the difference of ethylene production in different developmental stages.

The relationship of ACC oxidase (ACO) enzyme activity (Figure 6) and the ethylene production of transgenic Dendrobium orchid (Figure 7) indicated that the antisense $C P-A C O 1$ gene from papaya that was introduced into orchid genome is successfully express and reduce the production of ACO enzyme which reflected in the lower ACO activity and leading to the reduction of ethylene production. The transgenic Dendrobium 'Sonia Earsakul' produced $41-94.5 \%$ less ACO enzyme activity and $42-76 \%$ less ethylene than that of non-transgenic. This result confirms the successful of antisense technology across the plant classes of mono- and di-cotyledon(s). 


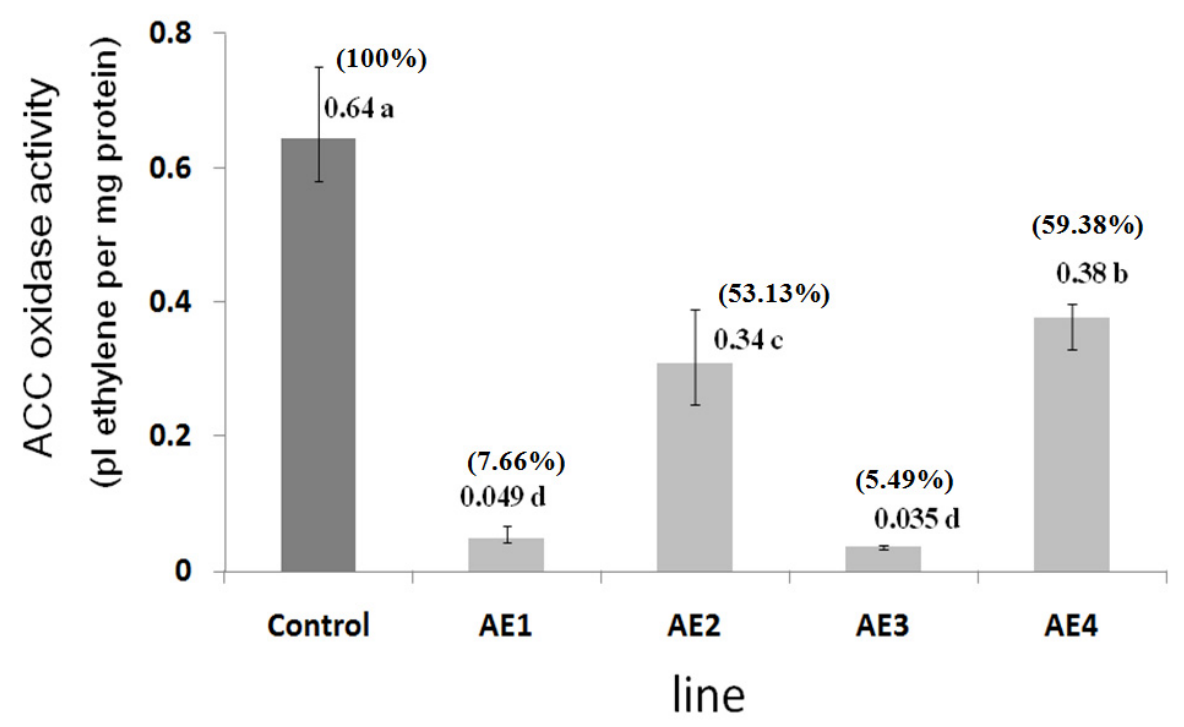

Figure 6. ACC oxidase (ACO) enzyme activity in mature leaves of 9-month-old of the transgenic Dendrobium 'Sonia Earsakul' lines AE1 AE2 AE3 and AE4 and non-transgenic line (control). (p $\leq 0.01)\left({ }_{-} \%\right)=\%$ of control

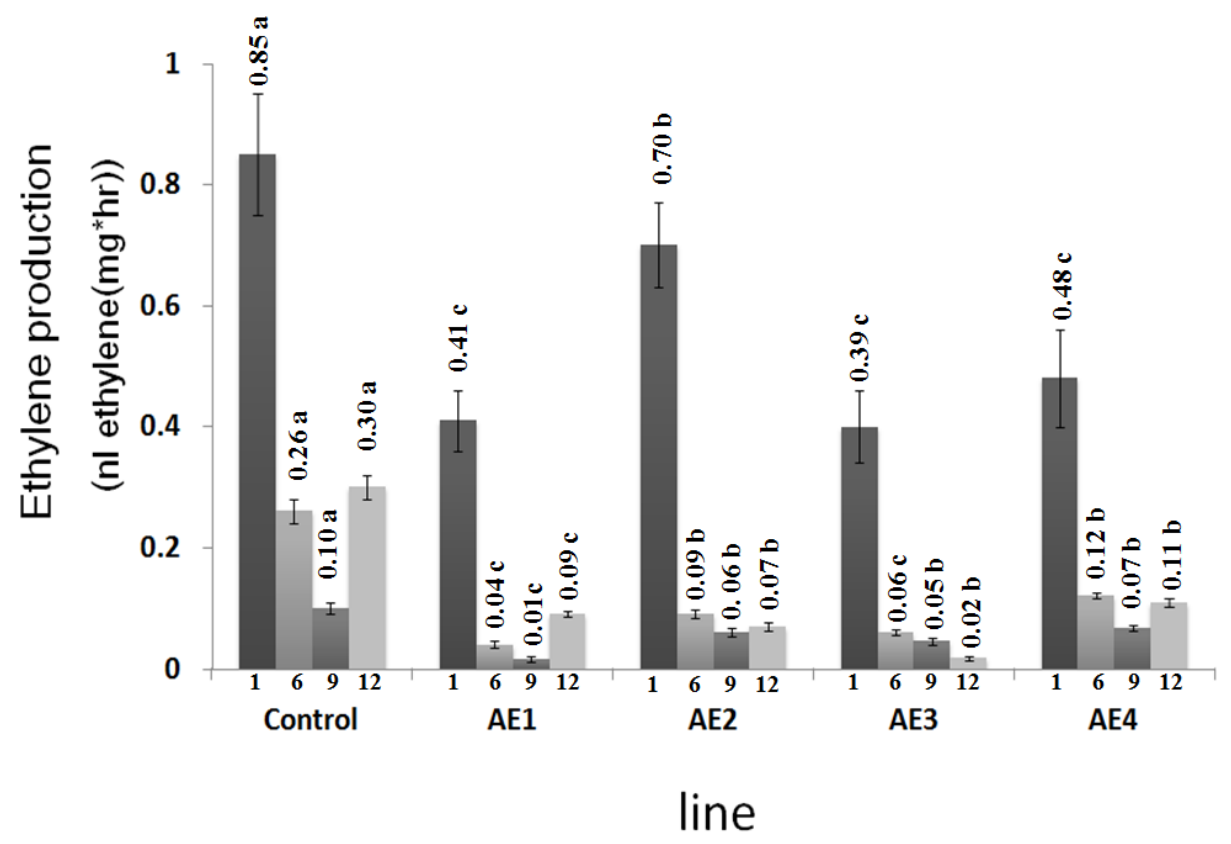

Figure 7. Ethylene production in mature leaves at 1,6,9 and 12 months after transplanting of transgenic Dendrobium 'Sonia Earsakul' lines (AE1 AE2 AE3 and AE4) and non-transgenic line (control).(p $\leq 0.01)$

\section{Conclusion}

Transgenic Dendrobium 'Sonia Earsakul' orchid possessing antisense $C P-A C O 1$ gene showed stability of the inserted gene detected by PCR technique and dot blot hybridization. Transgenic lines showed the existence of one to four sets of the gene in transgenic lines as detected by genomic Southern blot hybridization. Transgenic lines showed lower ACO enzyme activity and ethylene production than non transgenic orchid. 


\section{Acknowledgments}

This research was supported by the grant from the Center of Excellence on Agricultural Biotechnology, Science and Technology Postgraduate Education and Research Development Office, Office of Higher Education Commission, Ministry of Education (AG-BIO/PERDO-CHE) and also from the Center for Advanced Studies for Agriculture and Food, Institute for Advanced Studies, Kasetsart University under the Higher Education Research Promotion and National Research University Project of Thailand, Office of the Higher Education Commission, Ministry of Education, Thailand. We thank Mr. M. Cooper from International Affairs Division at Kamphaeng Saen, Kasetsart University for the kindness on review of the manuscript.

\section{References}

Abeles, F. B., Morgan, P. W., \& Saltveit, M. E. (1992). Ethylene in Plant Biology, second edition.Academic Press, New York. 414 p.

Aida, R., Kishimoto, S., Tanaka, Y., \&Shibata, M. (2000). Modification of flower colour in torenia (Torenia fournieri Lind.) by genetic transformation. Plant Science, 153, 33-42. http://dx.doi.org/10.1016/S0168-9452(99)00239-3

Ayub, R., Guis, M., Amor, M. B., Gillot, L., Roustan, J. P., Latché, A., Bouzayen, M., \& Pech., J. C. (1996). Expression of $A C C$ oxidase antisense gene inhibits ripening of cantaloupe melon fruits. Nature Biotechnology, 14, 862-866. http://dx.doi.org/10.1038/nbt0796-862

Bolitho, K. M., Lay-Yee, M., Knighton, M. L., \& Ross, G. S. (1997). Antisense apple ACC oxidase RNA reduces ethylene production in transgenic tomato fruit. Plant Science, 122, 91-99. http://dx.doi.org/10.1016/ S0168-9452(96)04532-3

Bovy, A. G., Angenent, G. C., Dons, H. J. M., \& Altvorst, A. C. (1999). Heterologous expression of the Arabidopsis etr1-1 allele inhibits the senescence of carnation flowers. Molecular Breeding, 5, 301-308. http://dx.doi.org/10.1023/A:1009617804359

Chin, D. P., Mishiba, K. I., \& Mii., M. (2007). Agrobacterium-mediated transformation of protocorm-like bodies in Cymbidium. Plant Cell Reports, 26, 735-743. http://dx.doi.org/10.1007/s00299-006-0284-5

De Mesa, M. C., Santiago-Dome'nech, N., Pliego-Alfaro, F., Quesada, M. A., \& Mercado, J. A. (2004). The CaMV 35S promoter is highly active on floral organs and pollen of transgenic strawberry plants. Plant Cell Report, 23, 32-38. http://dx.doi.org/10.1007/s00299-004-0776-0

Doyle, J. J., \& Doyle, J. L. (1987). Isolation of plant DNA from fresh tissue. Focus, 12, 13-15.

Einset, J. W. (1996). Differential expression of antisense in regenerated tobacco plants transformed with an antisense version of a tomato ACC oxidase gene. Plant Cell, Tissue Organ Culture, 46, 137-141. http://dx.doi.org/10.1007/BF00034847

Gao, M., Matsuta, N., Murayama, H., Toyomasu, T., Mitsuhashi, W., Dandekar, A. M., Tao, R., \& Nishimura, K. (2007). Gene expression and ethylene production in transgenic pear with sense or antisense cDNA encoding ACC oxidase. Plant Science, 173, 32-34. http://dx.doi.org/10.1016/j.plantsci.2007.03.014

Goh, C. J., Halevy, A. H., Engel, R., \& Kofranek, A. M. (1985). Ethylene evolution and sensitivity in cut orchid flowers. Scientia Horticulturae, 26, 57-67. http://dx.doi.org/10.1016/0304-4238(85)90102-5

Gupta, S. H., Srivastava, S., Gupta, S., \& Ahmed, Z. (2008). Genetic manipulation of fruit ripening: using antisense mRNA strategies. Journal of Applied Biosciences, 34, 115-123.

Hamilton, A. J., Lycett, G. W., \& Grierson, D. (1990). Antisense gene that inhibits synthesis of the hormone ethylene in transgenic plants. Nature, 346, 284-287. http://dx.doi.org/10.1038/346284a0

Henzi, M. X., McNeil, D. L., Christey, M. C., \& Lill, R. E. (1999). A tomato antisense 1-aminocyclopropane-1-carboxylic acid oxidase gene causes reduced ethylene production in transgenic broccoli. Australian Journal of Plant Physiology, 26, 179-183. http://dx.doi.org/10.1071/PP98083

Huang, L. C., Lai, U. L., Yang, S. F., Chu, M. J., Kuo, C. I., Tsai, M. F., \& Sun, C. W. (2007). Delayed flower senescence of Petunia hybrida plants transformed with antisense broccoli ACC synthase and ACC oxidase genes. Postharvest Biology and Technology, 46, 47-53. http://dx.doi.org/10.1016/j.postharvbio.2007.03.015

Kato, M., \& Hyodo, H. (1999). Purification and characterization of ACC oxidase and increase in its activity during ripening of pear fruit. Journal of the Japanese Society for Horticulture Science, 68, 551-557. http://doi.org/10.2503/jjshs.68.551 
Knoester, M., Linthorst, H. J. M., Bol, J. F., \& van Loon, L. C. (1997). Modulation of stress-inducible ethylene biosynthesis by sense and antisense gene expression in tobacco. Plant Science, 126, 173-183. http://dx.doi.org/10.1016/S0168-9452(97)00097-6

Men, S., Ming, X., Liu, R., Wei, C., \& Li, Y. (2003). Agrobacterium-mediated genetic transformation of a Dendrobium orchid. Plant Cell Tissue and Organ Culture, 75, 63-71.

Oeller, P. W., Lu, M. W., Taylor, L. P., Pike, D. A., \& Theologis, A. (1991). Reversible inhibition of tomato fruit senescence by antisense RNA. Science, 254, 437-439. http://dx.doi.org/ 10.1126/science.1925603

Piction, S., Barton, S. L., Bouzayen, M., Hamilton, A. J., \& Grierson, D. (1993). Altered fruit ripening and leaf senescence in tomatoes expressing an antisense ethylene-forming enzyme transgene. Plant Journal, 3, 469-481. http://dx.doi.org/ 10.1111/j.1365-313X.1993.tb00167.x

Pret'ov'a, A., Obert, B., \& Wetzstein, H. Y. (2001). Leaf developmental stage and tissue location affect the detection of $\beta$-glucuronidase in transgenic tobacco plants. Biotechnology Letter, 23, 555-558. http://dx.doi.org/ 10.1023/A:1010311524048

Savin, K. W., Baudinette, S. C., Graham, M. W., Michael, M. Z., Nugent, G. D., Lu, C. Y., Chandler, S. F., \& Cornish, E. C. (1995). Antisense ACC oxidase RNA delays carnation petal senescence. HortScience, 30, 970-972.

Scariot, V., R. Paradiso, H. Rogers \& S. De Pascale. (2014). Ethylene control in cut flowers: Classical and innovative approaches. Postharvest Biology and Technology, 97, 83-92. http://dx.doi.org/10.1016/j.postharvbio.2014.06.010

Silva, J. A., da Costa, T. S., Lucchetta, L., Marini, L. J., Zanuzo, M. R., Leonardo, N., Nora, F. R., Twyman, R. M., \& Rombaldi, C. V. (2004). Characterization of ripening behavior in transgenic melons expressing an antisense 1-aminocyclopropane -1-carboxylate (ACC) oxidase gene from apple. Postharvest Biology and Technology, 32, 263-268. http://dx.doi.org/10.1016/j.postharvbio.2004.01.002

Sjahril, R., Chin, D. P., Khan, R. S., Yamamura, S., Nakamura, I., Amemiya, Y., \& Mii, M. (2006). Transgenic Phalaenopsis plants with resistance to Erwinia carotovora produced by introducing wasabi defensin gene using Agrobacterium method. Plant Biotechnology, 23, 191-194. http://dx.doi.org/10.5511/plantbiotechnology.23.191

Stearns, J. C., \& Glick, B. R. (2003). Transgenic plants with altered ethylene biosynthesis or perception. Biotechnology Advances, 21, 193-210. http://dx.doi.org/10.1016/S0734-9750(03)00024-7

Vacin, E., \& Went, F.W. (1949). Some pH changes in nutrient solutions. Botanical Gazette, 110, 605-613.

Windels, P., De Buck, S., \& Depicker, A. (2008). Agrobacterium tumefaciens -mediated transformation: pattern of T-DNA integration into the host genome. pp. 441-481. In Tzfira V. and V. Citovsky. Agrobacterium from Biology to Biotechnology. Springer. New York.

Yang, S. F., \& Hoffman, N. E. (1984). Ethylene biosynthesis and its regulation in higher plants. Annual Review of Plant Physiology, 35, 155-189.

\section{Copyrights}

Copyright for this article is retained by the author(s), with first publication rights granted to the journal.

This is an open-access article distributed under the terms and conditions of the Creative Commons Attribution license (http://creativecommons.org/licenses/by/3.0/). 